\title{
EFFECT OF FOREST COVER ON ECTOPARASITES OF SMALL MAMMALS IN THE BRAZILIAN ATLANTIC FOREST
}

\author{
Norlan de Jesus Santos $^{1 *}$, Jacques Hubert Charles Delabie ${ }^{2}$, Danilo Gonçalves Saraiva ${ }^{3,5}$, \\ Fernanda Aparecida Nieri-Bastos ${ }^{3}$, Thiago Fernandes Martins ${ }^{3}$, Marcelo Bahia Labruna ${ }^{3}$, \\ Ianei de Oliveira Carneiro ${ }^{1}$ \& Carlos Roberto Franke 4
}

\footnotetext{
${ }^{1}$ Universidade Federal da Bahia, Departamento de Veterinária, Programa de Pós-Graduação em Ciência Animal nos Trópicos. Av. Adhemar de Barros, 500, Ondina, CEP 40170-110, Salvador, BA, Brazil.

2 Comissão Executiva do Plano da Lavoura Cacaueira, Centro de Pesquisas do Cacau, Laboratório de Mirmecologia, AC Itabuna, CEP 45600-970, Itabuna, BA, Brazil.

3 Universidade de São Paulo, Faculdade de Medicina Veterinária e Zootecnia, Departamento de Medicina Veterinária Preventiva e Saúde Animal, Av. Prof. Dr. Orlando Marques de Paiva, 87, Cidade Universitária, CEP 05508 270, São Paulo, SP, Brazil.

${ }^{4}$ Universidade Federal da Bahia, Departamento de Medicina Veterinária e Zootecnia. Av. Adhemar de Barros, 500, Ondina, CEP 40170-110, Salvador, BA, Brazil.

5 In memorian

E-mails: norlansantos@hotmail.com (*corresponding author); jacques.delabie@gmail.com; fenieri@usp.br; thiagodogo@hotmail.com; labruna@usp.br; ianeica@gmail.com; franke@ufba.br
}

\begin{abstract}
Habitat reduction is one of the greatest threats to biodiversity and one of its many expected consequences is the negative impacts on host species. In this study, we evaluated if the reduction in the forest cover positively affected the richness and abundance of ectoparasites and rates of parasitism on mammal species. The study was carried out in the Atlantic Forest biome in the state of Bahia between January to March and September to November of 2011. We sampled four areas with different amounts of forest cover (\%) in the municipalities of Valença (25\%), Nilo Peçanha (35\%), Camamú (45\%) and Jaguaripe (55\%). We identified twenty species of ectoparasites (fleas, mites, ticks) on 130 small mammals from 18 species (14 rodents and four marsupials), and the most abundant ectoparasites were mites. We confirmed our main hypothesis: the greater richness and abundance of ectoparasites was associated with a reduction in forest cover, with possible epidemiological implications. The prevalence of ectoparasitism per area varied from $91 \%$ in Valença to $50 \%$ in Jaguaripe. The mean intensity of ectoparasites per host was 6.5 for Valença, 6.4 for Nilo Peçanha, 10.4 for Camamú and 3.2 for Jaguaripe. Ours findings confirm that the reduction in the amount of forested is related to amplified rates of parasitism and changes in ectoparasites abundance and species richness.
\end{abstract}

Keywords: habitat reduction; parasitism; public health; vectors. 


\section{INTRODUCTION}

The process of reduction and fragmentation of natural habitats is one of the main threats to biodiversity (Fahrig 2003, Prugh et al. 2008) because, among other effects, it results in the loss of species, isolation of populations, increase of edge effects in fragments of native vegetation and reduction of the adaptive potential due to the loss of genetic variability (Rolstad 1991). The Atlantic Forest is considered one of the global hotspots of biodiversity, due to its biological richness and high number of endemic species (Myers et al. 2000). However, despite its ecological importance, the Atlantic Forest has suffered progressive reduction in its total area due to anthropogenic actions, whereby less than $15 \%$ of its original extension remains (SOS Mata Atlântica \& INPE 2016). This process results in a mosaic landscape made up of patches of original habitat (islands of habitat) surrounded by areas with different levels of human activity (altered matrices; Murcia 1995). One of the direct consequences of habitat reduction and fragmentation is the increase of border areas between forest fragments and altered landscapes (Gascon et al. 1999). This process enables the contact between wild hosts and domestic animals in the surrounding areas, which favors the exchange of parasites and the alteration of their community structures (Small \& Hunter 1975, Holmes 1996, Patten et al. 2006).

Parasites perform important functions within the ecosystem by, for example, affecting biodiversity (Stanko et al. 2002), reducing competition (Moore 2002), mediating interactions (Dunn et al. 2012), and causing impacts on reproduction and survival of their host species (Daszak et al. 2001). The invasion of parasites can result in the introduction of new diseases, endangering the survival of host species that are not yet adapted to new parasite species (Hudson et al. 2002). Concerning ectoparasites of mammals, the majority belongs to the classes Insecta and Arachnida, with the latter group represented mainly by the orders Astigmata, Gamasida, and Ixodida. In particular, ticks, hematophagous mites and fleas constitute groups of interest to Conservation Biology and Veterinary Medicine (Ribeiro et al. 1997, Labruna et al. 2000), since they may act as vectors of emerging diseases in Brazil, such as Brazilian spotted fever and ehrlichiosis (Labruna et al. 2004), which could infect wildlife, domestic animals and man (Fonseca et al. 2005).

Small mammals (marsupials and rodents) are hosts of several species of ectoparasites (Brooks \& Hoberg 2000, Saraiva et al. 2012). In Brazil, small mammals encompass more than 200 species and are considered the most diverse group among neotropical mammals (Paglia et al. 2012). They perform key ecological roles in the dynamic of the forests, such as predation and dispersion of seeds, and can be used as indicators of anthropogenic alterations (Brewer \& Rejmánek 1999). The density of these hosts seems to influence the distribution and abundance of ectoparasites, since the intensification of contact between the animals in a restricted area increases the probability of transmission (Arneberg et al. 1998, Morand \& Poulin 1998). Studies on parasite transmission evaluating the role of habitat reduction and increase in contact between hosts showed different results; Gillespie et al. (2005) and Mbora \& McPeek (2009) showed that the increase in contact between hosts was an important variable for the parasite transmission, abundance and, consequently, for the prevalence of endoparasites in non-human primates in Africa. On the other hand, neither Stanko et al. (2002) in mountains and forested plains in Slovakia, nor Püttker et. al. (2007) in areas of the Atlantic Forest in Brazil, have identified any association between the parasite load of small mammals and the state of vegetation cover.

In this study, we evaluated the prevalence, intensity and changes in ectoparasite community (richness and abundance) collected in small mammals in relation to the amount of forest cover in four areas in the Atlantic Forest, Brazil. In addition, we analyzed if the community structure of parasites differed between forested areas and the matrix. We expected an increase in the richness and abundance of ectoparasites in small mammals in areas with reduced forest cover.

\section{MATERIAL AND METHODS}

\section{Sample design}

The Atlantic Forest in the state of Bahia, Brazil, is considered one of the centers of regional ende- 
mism in the biome (Silva \& Casteleti 2003). It is currently dominated by secondary forest surrounded by a matrix of pasture intermixed with a variety of tree crops, including cocoa, rubber, bananas, palm oil, eucalyptus, and coffee, mainly in privately-owned land (Saatchi et al. 2001). The study region comprised the coastal strip of Atlantic Forest south to "Todos os Santos" Bay (1300'$14^{\circ} 50^{\prime} \mathrm{S}, 39^{\circ} 00^{\prime}-39^{\circ} 30^{\prime} \mathrm{W}$ ). We sampled four areas of $6 \times 6 \mathrm{~km}$ (3,600 ha) varying in the amount of remaining forest, in all of which altitude was less than $300 \mathrm{~m}$. Forest remnants were in mid to advanced stages of regeneration and the matrix was dominated by open areas.

We calculated forest cover, the size of the largest forest patch (Largest Patch Index; Mcgarigal \& Marks 1995) and the percentage of the matrix that is non-forested and non-urban based on recent satellite images (2005-2008) from the "Atlas of forest remnants of the Atlantic Forest" ("Atlas dos remanescentes florestais da Mata Atlântica"; www.sosma.org.br and www.inpe.br). We controlled for both forest cover and the size of the largest forest patch in the surrounding, larger areas, since both could act as source areas, thus considering only the $6 \times 6 \mathrm{~km}$ landscapes where forest cover and the size of the largest forest patches were larger than the observed in the surroundings (18 x $18 \mathrm{~km})$. We also controlled for the permeability of the matrix by considering only landscapes where at least $80 \%$ of the matrix presented low permeability, with vegetation height less than $2 \mathrm{~m}$. Thus, we not compute urban areas, tree plantations, such as cacao, pines, eucalyptus, and rubber trees, and young secondary forests. We then chose the sampled landscapes by randomizing their spatial distribution to avoid correlation between geographical position and percentage of forest cover (Figure 1). The four selected areas sampled in this study were located in the following municipalities: Valença (25\% of forest cover), Nilo Peçanha (35\%), Camamú (45\%), and Jaguaripe (55\%) (Figure 1).

Each of the four areas was divided into grids of 100 numbered plots of $600 \times 600 \mathrm{~m}$ for convenience and classified as either forest or matrix plots. We then randomly chose eight plots of each type (16 per area) to locate our sampling sites, which were checked in the field to guarantee that forests corresponded to secondary forest in mid to advanced stages of regeneration and the matrix to non-urban: open areas with vegetation height less than $2 \mathrm{~m}$. We ensured that in forest plots were settled in a minimum distance of $30 \mathrm{~m}$ to forest edge to reduce changes in forest cover as a result of the edge effect (Murcia 1995).

\section{Sampling of small mammal species}

We sampled small non-volant mammals (rodents and marsupials) in all 64 plots (eight forest and eight matrix sites in each of the four areas) using both pitfall traps (plastic buckets of 60-liter) not baited and medium-sized Sherman ${ }^{\circledR}(10 \times 10 \times 30$ $\mathrm{cm})$ and Tomahawk ${ }^{\circledR}(15 \times 17 \times 45 \mathrm{~cm})$ live traps. In each sampling site, we esta-blished ten equidistant pitfall traps connected by a $50 \mathrm{~cm}$ high plastic drift fence and 20 equidistant live traps on the ground (ten of each type) $5 \mathrm{~m}$ apart from each other. We baited the traps with a mixture of peanut butter, sunflowers seeds, oat grains, palm oil and sardines. The traps were active for eight days and inspected daily. The captured specimens were duly registered, following bioethical procedures and using license 12,023-4 from the Chico Mendes Institute for the Conservation of Biodiversity - ICMBio. All sites and landscapes were sampled between January to March and September to November of 2011. The 16 sites in a landscape were sampled simulta-neously and thus the sampling of each landscape took around ten days. We identified small mammals to species level using the external morphology, consulting the literature and specialists. Voucher specimens (of all species) were hosted at the Natural History Museum of the Federal University of Bahia.

\section{Collection and identification of ectoparasites}

Collected small mammals were placed in individual cotton bags and had their ectoparasites collected through direct inspection of the corporal surface and brushing. The instruments used in the collection of the ectoparasites were sanitized between each collection. The parasites were put in microtubes containing ethanol and identified concerning the location of collection and the host. 


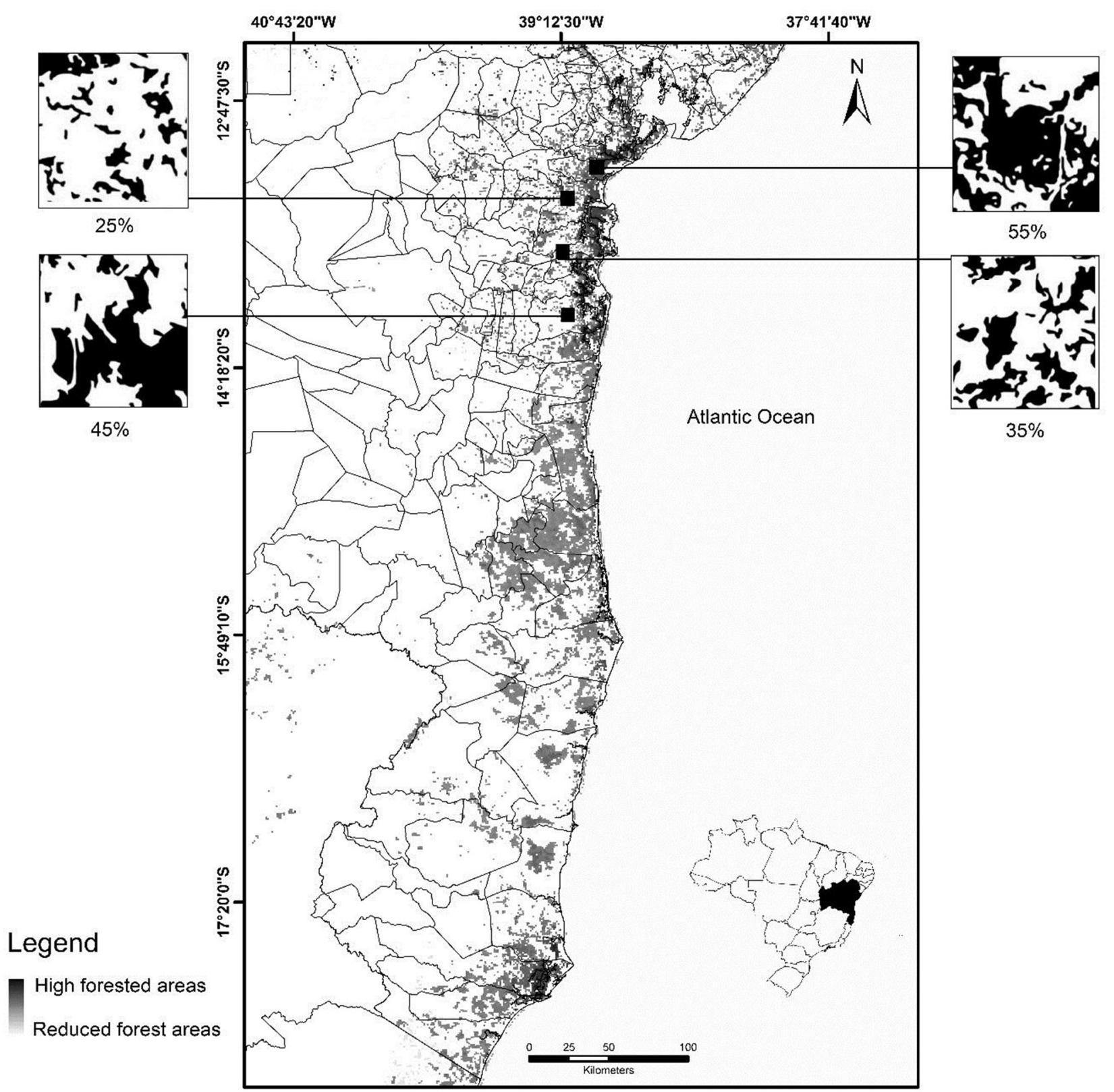

Figure 1. Map showing the position of the state of Bahia, Brazil, and the location where four sampled areas (back squares) were established with the respective percentages of forest cover.

At the end of each sample week, the contents in the microtubes were sent to the Laboratory of Parasitic Diseases at the Department of Veterinary Medicine and Animal Health of the University of São Paulo ("Laboratório de Doenças Parasitárias do Departamento de Medicina Veterinária e Saúde Animal da Universidade de São Paulo"), where they were identified. The identification of the ectoparasites was undertaken with stereo microscope according to Fonseca $(1936,1939)$ for mites, Linardi \& Guimarães (2000) for fleas, and Onofrio et al. (2009) and Martins et al. (2010) for ticks.

\section{Data analysis}

The analyses were carried out with the IBM SPSS Statistics 21 program and the significance level adopted for all the tests was 5\% ( $\alpha=0.05)$. Normality was evaluated using a KolmogorovSmirnov test. We applied Mann-Whitney U test to evaluate possible differences in the richness and abundance of the parasite specimens between the forest and the matrix. Additionally, a KruskalWallis test was performed in order to compare parasite richness and abundance using the percentage of forest cover as group variable. The 
host abundance was compared using One-Way ANOVA to evaluate significant differences using the percentage of forest cover as a factor. Additionally, the Spearman correlation was performed between the abundance and richness of host and abundance and richness of ectoparasites.

The prevalence of ectoparasitism per area was estimated as the percentage of the number of infested individuals over the total of individuals analysed in the study. Intensity of the infestation was estimated as the rate between the number of ectoparasites collected and the number of infested hosts in each area.

\section{RESULTS}

A total of 130 small mammals of 18 different species were captured (14 rodents and four marsupials) (Table 1). The most abundant species were the rodents Akodon cursor (Rodentia, Cricetidae; $\mathrm{N}=30$ ) and Necromys lasiurus (Rodentia, Cricetidae; $\mathrm{N}=22$ ) and the marsupial Metachirus nudicaudatus (Didelphimorphia, Didelphidae; $\mathrm{N}=13$ ), with the exception of Camamú municipality where M. nudicaudatus was not found (Table 1). Twenty species of ectoparasites were identified. The following species of mites were the most abundant in the set of the four areas: Androlaelaps rotundus (Acari, Laelapidae; $\mathrm{N}=328$ ), Gigantolaelaps oudemansi (Acari, Laelapidae; $\mathrm{N}=78$ ) and Gigantolaelaps mattogrossensis (Acari, Laelapidae; $\mathrm{N}=64$ ). The most abundant species of ticks were Amblyomma sp. (Acari, Laelapidae; $\mathrm{N}=26$ larvae), Ixodes sp. (Acari, Laelapidae; $\mathrm{N}=18$ larvae) and Amblyomma ovale (Acari, Ixodidae; $\mathrm{N}=17$ nymphs). The most abundant flea genus in the landscapes was Polygenis sp. (Siphonaptera, $\mathrm{N}=28$ ).

The highest number of ectoparasites was found in the area with less percentage of forest cover (Figure 2). With a reduction in forest cover, there was an increase in the abundance of ectoparasites with the following differences between the areas: $25 \%$ and $35 \%$ of forest cover ( $p=0.01$ ), $25 \%$ and $55 \%$ of forest cover $(\mathrm{p}<0.001)$, and $45 \%$ and $55 \%$ of forest cover $(p<0.001)$. The abundance of hosts showed no difference between the four areas sampled (ANOVA, $\mathrm{F}_{3,130}=0.851, \mathrm{p}=0.473$; Table 1). No correlation was observed either between ectoparasite and host species richness (Rs = 0.046; $\mathrm{p}=0.599$ ) or between ectoparasite and host abundance (Rs $=-0.085 ; \mathrm{p}=0.334)$.

There was no difference between the set of ectoparasites collected in the forest and in the matrix, both in terms of richness $(\mathrm{U}=1785.0 ; \mathrm{p}=$ 0.086) and abundance $(U=1991.5 ; \mathrm{p}=0.719)$. However, the richness of ectoparasites differed between the plots located in the study areas $\left(\chi^{2}{ }_{3}=\right.$ 25.16; $\mathrm{p} \leq$ 0.001) (Figure 3) .

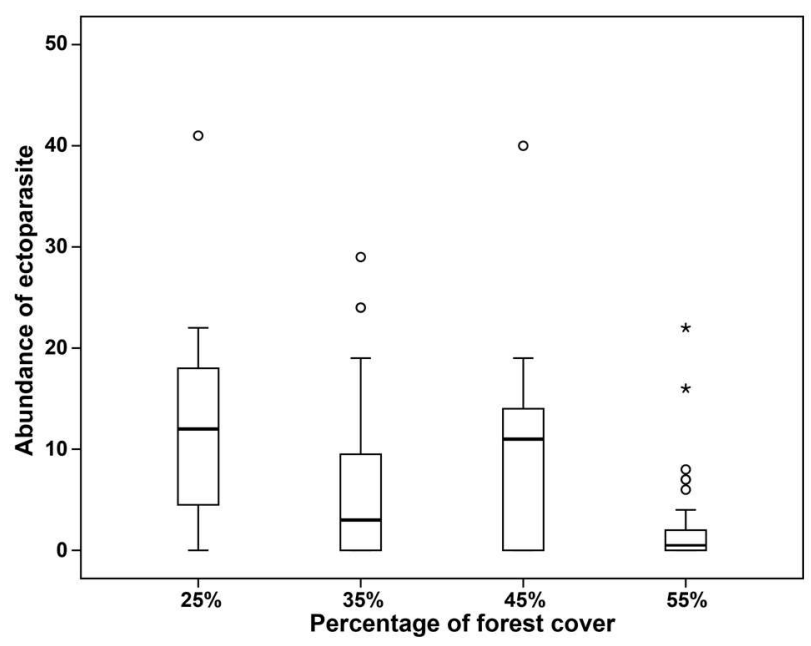

Figure 2. Box plot (median, interquartile and outlierswhite dot) presenting the abundance of ectoparasites in relation to the percentage of forested cover.

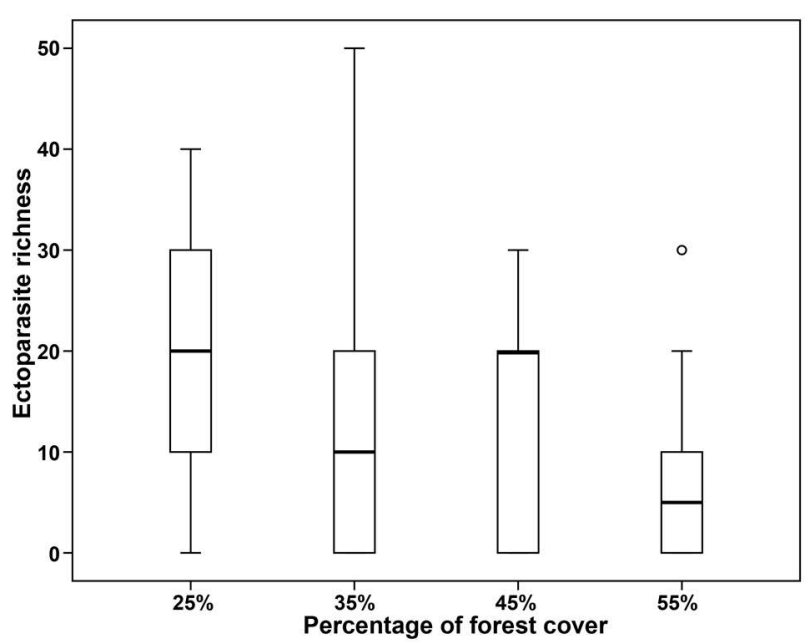

Figure 3. Box plot (median, interquartile and outlierswhite dot) presenting the richness of ectoparasites in relation to the percentage of forested cover.

The post-hoc tests identified differences between the area with $25 \%$ of forest cover (Valença) and the areas with $35 \%(p=0.01)$ and $55 \%(\mathrm{p}<0.01)$ of forest cover (Jaguaripe). The prevalence of ectoparasitism per area was $91 \%$ in the area with $25 \%$ of forest cover, $64 \%$ in the area 
Table 1. Prevalence and intensity (median) of ectoparasitism in small wild mammals in four areas with $25 \%$ (a), 35\% (b), $45 \%$ (c) and 55\% (d) of Atlantic Forest cover in the state of Bahia, Brazil.

\begin{tabular}{|c|c|c|c|}
\hline Hosts & $\mathbf{N}$ & Infested & Intensity \\
\hline \multicolumn{4}{|l|}{ a) $\mathbf{2 5 \%}$ forest cover } \\
\hline Akodon cursor & 7 & 6 & 68 \\
\hline Cavia aperea & 1 & 0 & 0 \\
\hline Cerradomys vivoi & 3 & 3 & 42 \\
\hline Euryoryzomys russatus & 1 & 1 & 15 \\
\hline Holochilus brasiliensis & 1 & 1 & 19 \\
\hline Metachirus nudicaudatus & 2 & 2 & 40 \\
\hline Necromys lasiurus & 5 & 5 & 40 \\
\hline Oligoryzomys sp. & 1 & 1 & 15 \\
\hline Pseudoryzomys simplex & 1 & 1 & 41 \\
\hline Trinomys sp. & 2 & 2 & 21 \\
\hline \multicolumn{4}{|l|}{ b) $\mathbf{3 5 \%}$ forest cover } \\
\hline Akodon cursor & 7 & 6 & 70 \\
\hline Cerradomys vivoi & 3 & 3 & 21 \\
\hline Cryptonanus sp. & 1 & 1 & 5 \\
\hline Hylaeamys laticeps & 4 & 3 & 22 \\
\hline Marmosops incanus & 6 & 4 & 45 \\
\hline Marmosa murina & 3 & 2 & 4 \\
\hline Metachirus nudicaudatus & 6 & 3 & 15 \\
\hline Micoureus demerarae & 1 & 0 & - \\
\hline Necromys lasiurus & 10 & 6 & 61 \\
\hline Pseudoryzomys simplex & 2 & 1 & 10 \\
\hline Rattus sp. & 1 & 1 & 1 \\
\hline Rhipidomys mastacalis & 1 & 0 & - \\
\hline Trinomys sp. & 3 & 2 & 22 \\
\hline \multicolumn{4}{|l|}{ c) $45 \%$ forest cover } \\
\hline Akodon cursor & 5 & 4 & 67 \\
\hline Cerradomys vivoi & 1 & 1 & 11 \\
\hline Didelphis aurita & 1 & 0 & 14 \\
\hline Euryoryzomys russatus & 3 & 2 & 16 \\
\hline Hylaeamys laticeps & 8 & 6 & 99 \\
\hline Monodelphis americana & 2 & 1 & 8 \\
\hline Necromys lasiurus & 2 & 0 & - \\
\hline Pseudoryzomys simplex & 3 & 3 & 31 \\
\hline \multicolumn{4}{|l|}{ d) $55 \%$ forest cover } \\
\hline Akodon cursor & 10 & 4 & 18 \\
\hline Cerradomys vivoi & 3 & 3 & 23 \\
\hline Didelphis aurita & 3 & 1 & 4 \\
\hline Marmosops incanus & 6 & 0 & - \\
\hline Metachirus nudicaudatus & 5 & 4 & 32 \\
\hline Necromys lasiurus & 5 & 5 & 6 \\
\hline Rattus sp. & 1 & 0 & - \\
\hline
\end{tabular}


with $35 \%$ of forest cover, $68 \%$ in the area with $45 \%$ of forest cover, and $50 \%$ in the area with $55 \%$ of forest cover. The intensity of ectoparasitism (number of ectoparasites per host) was 13.6 in Valença, 8.9 in Nilo Peçanha, 13.6 in Camamú, and 4.8 in Jaguaripe (Table 2).

\section{DISCUSSION}

Our results confirm that the reduction in the amount of forested cover acts as a factor intensifying the rate of parasitism and affects the abundance and species richness of ectoparasites. As expected, host species that were in areas with less amount of forested cover (25\% of forest cover) had higher infestation rates when compared to the other plots, resulting in a greater abundance of ectoparasites in these areas. The differences in ectoparasite richness and abundance between areas with reduced forest cover can be the result of the influence of the matrix areas surrounding the fragments. This influence was identified for others animal groups in forest fragments with different levels of human activity in the Amazon region (Gascon et al. 1999). The increase in the abundance of ectoparasites in the plots located in landscapes with the lowest percentage of forest cover $(25 \%)$ could be partially explained by the greater tolerance of the habitat generalists hosts for degraded areas.

The infestation rates with ectoparasites in small mammals are within the range recorded by other authors in studies with small mammals $33.3 \%$ in Yoshizawa et al. 1996, 69.1\% in Perez et al. 2008). Of the 20 species of ectoparasites identified, the highest amount of infestation was caused by Laelapidae mites (Nieri-Bastos et al. 2004, Reis et al. 2008). In the current study, Ixodidae ticks also infested both rodents and marsupials (Barros \& Baggio 1992, Nieri-Bastos et al. 2011). We encourage more studies assessing the specificity of these parasites in the choice of their host in the natural environment. On the other hand, the ticks

Table 2. Ectoparasites in small mammals of four areas with $25 \%, 35 \%, 45 \%$ and $55 \%$ of Atlantic Forest cover in the state of Bahia, Brazil. Amblyomma sp. and Ixodes sp. were all larvae, A. dubitatum and A. ovale were nymphs, and $I$. loricatus were adult ticks.

\begin{tabular}{|c|c|c|c|c|}
\hline Taxa & $25 \%$ & $35 \%$ & $45 \%$ & $\mathbf{5 5 \%}$ \\
\hline \multicolumn{5}{|l|}{ Ticks } \\
\hline Amblyomma sp. & $\mathrm{X}$ & $\mathrm{X}$ & $\mathrm{X}$ & $\mathrm{X}$ \\
\hline Amblyomma dubitatum & & $\mathrm{X}$ & & \\
\hline Amblyomma ovale & $\mathrm{X}$ & & $\mathrm{X}$ & $\mathrm{X}$ \\
\hline Ixodes loricatus & $\mathrm{X}$ & & & $\mathrm{X}$ \\
\hline \multicolumn{5}{|l|}{ Mites } \\
\hline Androlaelaps sp. & $\mathrm{X}$ & & $\mathrm{X}$ & \\
\hline Androlaelaps cuicensis & & & $\mathrm{X}$ & \\
\hline Androlaelaps fahrenholzi & $\mathrm{X}$ & $\mathrm{X}$ & $\mathrm{X}$ & \\
\hline Androlaelaps marmosops & $\mathrm{X}$ & & & \\
\hline Androlaelaps rotundus & $\mathrm{X}$ & $\mathrm{X}$ & $\mathrm{X}$ & $\mathrm{X}$ \\
\hline Gigantolaelaps gilmorei & $\mathrm{X}$ & & $\mathrm{X}$ & \\
\hline Gigantolaelaps mattogrossensis & $\mathrm{X}$ & & & \\
\hline Gigantolaelaps cf. matogrossensis & & & $\mathrm{X}$ & \\
\hline Gigantolaelaps oudemansi & $\mathrm{X}$ & $\mathrm{X}$ & $\mathrm{X}$ & \\
\hline Gigantolaelaps vitzthumi & $\mathrm{X}$ & $\mathrm{X}$ & $\mathrm{X}$ & \\
\hline Gigantolaelaps wolffsohni & $\mathrm{X}$ & & & \\
\hline Laelaps sp. & $\mathrm{X}$ & $\mathrm{X}$ & $\mathrm{X}$ & \\
\hline \multicolumn{5}{|l|}{ Laelaps manguinhosi } \\
\hline Laelaps paulistanensis & $\mathrm{X}$ & & & \\
\hline Ornythonyssus sp. & & $\mathrm{X}$ & $\mathrm{X}$ & \\
\hline Tur turki & & $\mathrm{X}$ & $\mathrm{X}$ & \\
\hline \multicolumn{5}{|l|}{ Fleas } \\
\hline Poligenys sp. & $\mathrm{X}$ & $\mathrm{X}$ & $\mathrm{X}$ & $\mathrm{X}$ \\
\hline
\end{tabular}


A. dubitatum and A. ovale infesting small rodents corroborate observations of Szabó et al. (2013) and Debárbora et al. (2014). In this study, fleas from the genus Polygenis (Siphonaptera) were found both on Echimyidae and Cricetidae rodents, as well as on the Didelphidae marsupials. This result is similar to Linardi (1985), which discussed the fact that the Rhopalopsyllidae did not demonstrate specificity as to their choice of host.

Several species of ticks related to the transmission of emerging zoonosis in Brazil were identified, such as A. ovale, which is involved in the transmission of Rickettsia parkeri (Rickettsiales, Rickettsiaceae), responsible for mild rickettsial infection in areas of the Atlantic Forest biome (Sabatini et al. 2010, Szabó et al. 2013). Additionally, Macronyssidae mites are considered hematophagous parasites and result in additional risk to human health, since some species are etiological agents of dermatitis (Ribeiro et al. 1997). In Brazil, the majority of fleas (Siphonaptera) belongs to the genus Polygenis (Rhopanopsyllidae; Dobbin et al. 1969, Linardi et al. 1987) and can act as vectors of the bubonic plague, whose etiological agent is the bacteria Yersinia pestis (Enterobacteriales, Yersiniaceae), a factor which elevates the importance of our scientific findings (Ruiz 2001).

The lack of difference in richness and abundance of ectoparasites between the forest and the matrix suggests that ectoparasites have no difficulties in transiting across the landscape, which probably occurs due to the movement of wild and domestic animals between the forest and the matrix (Gascon et al. 1999). This result was observed in a study that evaluated the influence of the characteristics of different matrix and tropical forest fragments in the Central Amazonia in relation to, among other aspects, the distribution of small mammal species (Gascon et al. 1999). Several species of vertebrates in forest fragments use the surrounding matrix for movement and reproduction, as observed in small mammals of semi-deciduous forest fragments (Santos-Filho \& Sanaiotti 2008).

The increase in the number of species of ectoparasites with the decrease in forest cover found in this study could be explained, at least in part, by the increase in contact between the hosts with distinct habitats. It is important to consider that animals in areas with lower amount of forested cover may explore better the surrounding areas (matrix) enabling parasites exchange (Gillespie et al. 2005, Püttker et al. 2007, Mbora \& McPeek 2009).

Both the prevalence and the intensity of infestation in small mammals by ectoparasites presented higher levels in the areas with less forest cover $(91 \%$ prevalence and a 6.5 infestation intensity), and lower levels in the areas with high forest cover $(50 \%$ prevalence and 3.2 infestation intensity). Although it was necessary to test statistically the mean values of prevalence and intensity of infestation by ectoparasites in the four areas suggest that a reduction in forest covered habitat could, through parasitism, play an important role in the dynamic and health of small mammals in the Atlantic Forest. These results suggest a positive relationship between the reduction in the forested area and the increase in ectoparasites of small mammals, which may lead to an increase in the risk of infestation and, consequently, compromise the health of wild and domestic animals and humans.

The host species found in this study were similar with the ones found in surveys performed in areas of the Atlantic Forest in the states of Bahia (Moura 2003) and Espírito Santo (Pinto et al. 2009). Among the 18 small mammals identified, only three (A. cursor, Marmosops incanus [Didelphimorphia, Didelphidae] and $N$. lasiurus) were common to all the units, and the first two were also found by Moura (2003) and Pinto et al. (2009). Although there is a need for larger and more complex studies about the distribution of host species, the identification of similar ectoparasite species in different areas of the Atlantic Forest shows that they are widely distributed. The abundance of hosts collected showed no significant variation among areas, corroborating other comparative studies of abundance of small mammals in different areas of the Atlantic Forest in the state of São Paulo (Pardini et al. 2009). Such results can suggest a resilience of habitat generalists host species to modifications of the forested landscapes. Furthermore, similarities in the abundance of host species among areas reduce the possible influence 
of the quantity of small mammals on the rates of parasitism.

The habitat reduction process appears to play a key role in changes in ectoparasitism of small mammals in the Atlantic Forest. It is necessary to investigate the negative impacts of these changes to the population of hosts. Additionally, we emphasize the importance of undertaking molecular evaluations of the ectoparasites to investigate the presence of potential pathogens which cause zoonosis in Brazil. It is important to emphasize that many parasites only occur in preserved areas. Preserved areas may have more species of parasites because they may have greater diversity of host species, and many parasites are important for the stability of interactions in ecosystems. Not all parasites are pathogenic to human being and most are species-specific. Preserved areas must be maintained to sustain the biodiversity and are important to dilute the prevalence of a pathogenic parasite that causes a zoonosis. Our results can be used as a warning for a possible problem of natural areas because they reinforce the importance of maintaining the forest cover as a way of balance the rates of parasitism, conservation of populations of small mammals, and the reduction of risks to public health.

\section{ACKNOWLEDGEMENTS}

We strongly thank the team of the "Projeto Limiares de Extinção" - INOMEP/PRONEX, the specialists Yuri Leite and Leonora Costa from Universidade Federal do Espirito Santo for the help in developing the current study. Also thanks are extended to the post-graduate program in Ecologia e Biomonitoramento da Universidade Federal da Bahia - UFBA as well as to IBAMA-BA, Odebrecht and Rio Tinto for ceding field vehicles to undertake the field activities for the Project. Thanks are also in order to the fomenting agencies FAPESB and CNPq (grant terms APP0049/2009 and PNX0016/2009) for ceding financial resources for the development of the Project, as well as CAPES for the grant for the Master's Degree of Norlan Santos during the development of the project. We also thank: Elen Santos da Paz, Vanuza Gazar, Ricardo Lustosa, Mauro Ramalho, and Cléa Mariano.

\section{REFERENCES}

Arneberg, P., Skorping, A., Grenfell, B., \& Read, A. F. 1998. Host densities as determinants of abundance in parasite communities. Proceedings of the Royal Society. Biological Sciences, 265, 1283-1289. DOI: 10.1098/rspb.19 98.0431

Barros, D. M., \& Baggio, D. 1992. Ectoparasites (Ixodida Leach, 1817) on wild mammals in the State of Paraná, Brazil. Memórias do Instituto Osvaldo Cruz, 87(2), 291-296. DOI: 10.15 90/S0074-02761992000200018

Brewer, S. W., \& Rejmánek, M. 1999. Small rodents as significant dispersers of tree seeds in a Neotropical forest. Journal of Vegetation Science, 10(2), 165-174. DOI: 10.2307/3237138

Brooks, D. R., \& Hoberg, E. P. 2000. Triage for the biosphere: the need and rationale for taxonomic inventories and phylogenetic studies of parasites. Journal of the Helminthological Society of Washington, 67(1), 1-25.

Daszak, P., Cunningham, A. A., \& Hyatt, A. D. 2001. Anthropogenic environmental change and the emergence of infectious diseases in wildlife. Acta Tropica, 78, 103-16. DOI: 10.1016/S0001-70 6X(00)00179-0

Debárbora, V. N., Mangold, A. J., Eberhardt, A., Guglielmone, A. A., \& Nava, S. 2014. Natural infestation of Hydrochoerus hydrochaeris by Amblyomma dubitatum ticks. Experimental and Applied Acarology, 63 (2), 285-94. DOI: 10.1007/ s10493-014-9768-0

Dobbin, J., Valença, J. R., \& Cruz, A. E. 1969. Alguns informes sobre pulicídeos de chão de habitações e de animais silvestres do nordeste brasileiro. Revista Brasileira de Doenças Tropicais, 21, 733-758.

Dunn, A. M., Torchin, M. E., Hatcher, M. J., Kotanen, P. M., Blumenthal, D. M., Byers, J. E., Kanarek, A. R. Courtney, A. C., Coon, V. M., Frankel, R. D. H., Ruth, A. H., Andrew, R. K., Kristina, A. S., Lorne, M. W., \& Sarah, E. P. 2012. Indirect effects of parasites in invasions. Functional Ecology, 26, 1262-1274. DOI: 10.11 $11 / j .1365-2435.2012 .02041 . x$

Fahrig, L. 2003. Effects of habitat fragmentation on biodiversity. Annual Review of Ecology, Evolution, and Systematics, 34(1), 487-515. DOI: 10.1146/annurev.ecolsys.34.011802.132419 
Fonseca, A. H., Salles, R. S., Salles, S. A. N., Madureira, R. C., \& Yoshinari, N. H. 2005. Borreliose de Lyme simile: uma doença emergente e relevante para a dermatologia no Brasil. Anais Brasileiros de Dermatologia, 80, 171-178.

Fonseca, F. 1936. Notas de Acarologia XX. Espécies novas de acarianos do gênero Laelaps, parasitas de ratos do Brasil (Acari: Laelaptidae). Memórias do Instituto Butantan, 10, 33-37.

Fonseca, F. 1939. Novos estudos sobre o gênero Laelaps Koch, 1836 (Acari: Laelapidae). Memórias do Instituto Butantan, 12, 103-123.

Gascon, C., Lovejoy, T. E., Bierregaard, R. O., Malcolm, J. R., Stouffer, P. C.,Vasconcelos, H. L., Laurance, W. F., Zimmerman, B., Tocher, M., \& Borges, S. 1999. Matrix habitat and species richness in tropical forest remnants. Biological Conservation, 91, 223-229. DOI: 10.1016/S00063207(99)00080-4

Gillespie, T. R., Chapman, C. A., \& Greiner, E. C. 2005. Effects of logging on gastrointestinal parasite infections and infection risk in african primates. Journal of Applied Ecology, 42, 699707. DOI: 10.1111/j.1365-2664.2005.01049.x

Holmes, J. C. 1996. Parasites as threats to biodiversity in shrinking ecosystems. Biodiversity and Conservation, 5, 975-983. DOI: 10.10 $07 / \mathrm{BF} 00054415$

Hudson, P. J., Dobson, A. P., Cattadori, I. M., Newborn, D., Haydon, D. T., Shaw, D. J., Benton, T. G., \& Grenfell, B. T. 2002. Trophic interactions and population growth rates: describing patterns and identifying mechanisms. Philosophical Transactions of the Royal Society of London. Series B, Biological sciences, 357, 1259-71. DOI: 10.1098/rstb.2002.1126

Labruna, M. B., Homem, V. S., Heinemann, M. B., \& Ferreira, N. J. S. 2000. Ticks (Acari: Ixodidae) associated with rural dogs in Uruará, eastern Amazon, Brazil. Journal of Medical Entomology, 37, 774-6. DOI: 10.1603/0022-2585-37.5.774

Labruna, M. B., Pinter, A., \& Teixeira, R. H. 2004. Life cycle of Amblyomma cooperi (Acari: Ixodidae) using capybaras (Hydrochaeris hydrochaeris) as hosts. Experimental and Applied Acarology, 32, 79-88. DOI: 10.1023/B:A PPA.0000018228.05088.26

Linardi, P. 1985. Dados complementares sobre hospedeiros de sifonápteros ropalopsilinos. Revista Brasileira de Biologia, 45, 73-78.
Linardi, P. M., Teixeira, V. P., Botelho, J. R., \& Ribeiro, L. S. 1987. Ectoparasitos de roedores em ambientes silvestres do município de Juiz de Fora, Minas Gerais, Brasil. Memorias do Instituto Osvaldo Cruz, 82, 137-139. DOI: 10.1590/S0 074-02761987000100022

Linardi, P. M., \& Guimarães, L. R. 2000. Sinfonápteros do Brasil. São Paulo: MZUSP/ FAPESB: p. 291.

Martins, T. F., Onofrio, V. C., Barros-Battesti, D. M., \& Labruna, M. B. 2010. Nymphs of the genus Amblyomma (Acari: Ixodidae) of Brazil: descriptions, redescriptions, and identification key. Ticks and Tick-borne Diseases, 1, 75-99. DOI: 10.1016/j.ttbdis.2010.03.002

Mbora, D. N. M., \& Mcpeek, M. A. 2009. Host density and human activities mediate increased parasite prevalence and richness in primates threatened by habitat loss and fragmentation. Journal of Animal Ecology, 78, 210-8. DOI: 10.1111/j.1365-2656.2008.01481.x

McGarigal, K., \& Marks, B. J. 1995. FRAGSTATS: spatial pattern analysis program for quantifying landscape structure. Gen Tech Rep PNW-GTR351. OR Portland. U.S. Department of Agriculture, Forest Service, Pacific Northwest Research Station. p. 122.

Moore, J. 2002. Parasites and the Behavior of Animals. Oxford: Oxford University Press: p. 338.

Morand, S., \& Poulin, R. 1998. Density, body mass and parasite species richness of terrestrial mammals. Evolutionary Ecology, 12, 717-727. DOI: 10.1023/A:1006537600093

Moura, R. T. 2003. Distribuição e ocorrência de mamíferos na mata atlântica do sul da Bahia. Corredores da Biodiversidade da Mata Atlântica do Sul da Bahia. Instituto de Estudos SócioAmbientais do Sul da Bahia e Conservation International do Brasil, 1-22.

Murcia, C. 1995. Edge effects in fragmented forests: implications for conservation. Trends in Ecology and Evolution, 10(2), 58-62. DOI: 10.10 16/S0169-5347(00)88977-6

Myers, N., Mittermeier, R. A., Mittermeier, C. G., Fonseca, G. A., \& Kent, J. 2000. Biodiversity hotspots for conservation priorities. Nature, 403, 853-858. doi:10.1038/35002501

Nieri-Bastos, F. A., Barros-Battesti, D. M., Linardi, P. M., Amaku, M. , Marcili, A., Favoreto, S. E., \& 
Pinto-da-Rocha, R. 2004. Ectoparasites of wild rodents from parque estadual da cantareira (pedra grande nuclei), São Paulo, Brazil. Revista Brasileira de Parasitologia Veterinária, 13(1), 2935

Nieri-Bastos, F. A., Labruna, M. B., Marcili, A., Durden, L. A., Mendoza-Uribe, L., \& BarrosBattesti, D. M. 2011. Morphological and molecular analysis of Ornithonyssus spp. (Acari: Macronyssidae) from small terrestrial mammals in Brazil. Experimental and Apllied Acarology, 55(4), 305-327. DOI: 10.1007/s10493-011-9475-Z

Onofrio, V. C., Barros-Battesti, D. M., Labruna, M. B., \& Faccini, J. L. H. 2009. Diagnoses of and illustrated key to the species of Ixodes Latreille, 1795 (Acari: Ixodidae) from Brazil. Systematic Parasitology, 72(2), 143-57. DOI: 10.1007/s1123 0-008-9169-z

Paglia, A. P., Rylands, A. B., Herrmann, G., Aguiar, L. M. S., Chiarello, A. G., Leite, Y. L. R., Costa, L. P., Siciliano, S., Mittermeier, R. A., \& Patton, J. L. 2012. Lista anotada dos mamíferos do Brasil. 2nd edition. Occasional Papers in Conservation Biology, 6, 1-76.

Pardini, R., Faria, D., Accacio, G. M., Laps, R. R., Mariano-Neto, E., Paciencia, M. L. B., Dixo, M., \& Baumgarten, J. 2009. The challenge of maintaining Atlantic forest biodiversity: a multitaxa conservation assessment of specialist and generalist species in an agro-forestry mosaic in southern Bahia. Biological Conservation, 142(6), 1178-1190. DOI: 10.1016/j.biocon.2009.02.010

Patten, M. A., Shochat, E., Reinking, D. L., Wolfe, D. H., \& Sherrod, S. K. 2006. Habitat edge, land management, and rates of brood parasitism in tallgrass prairie. Ecological Applications, 16(2), 687-95. DOI: 10.1890/1051-0761(2006)016[0687: HELMAR]2.0.CO;2

Perez, C. A., Almeida, F. A., Almeida, A., Carvalho, V. H. B., Balestrin, D. C., Guimarães, M. S., Costa, J. C., Ramos, L. A., Arruda-Santos, A. D., Maximo-Espindola, C. P., \& Battesti-Barros, D. M. 2008. Carrapatos do gênero Amblyomma (Acari: Ixodidae) e suas relações com os hospedeiros em área endêmica para febre maculosa no estado de São Paulo. Revista Brasileira de Parasitologia Veterinária, 17(4), 210-217. DOI: $10.1590 / S 1984-296120080004000$ 08
Pinto, I. D. S., Loss, A. C. C., Falqueto, A., \& Leite. Y. L. R. 2009. Pequenos mamíferos não voadores em fragmentos de Mata Atlântica e áreas agrícolas em Viana, Espírito Santo, Brasil. Biota Neotropica, 9(3), 355-360. DOI: 10.1590/S167606032009000300030

Prugh, L. R., Hodges, K. E., Sinclair, A. R. E., \& Brashares, S. 2008. Effect of habitat area and isolation on fragmented animal populations. Proceedings of the National Academy of Sciences of the United States of America, 105(52), 20770-20775. DOI: 10.1073/pnas.0806 080105

Püttker, T., Meyer-Lucht, Y., \& Sommer, S. 2007. Effects of fragmentation on parasite burden (nematodes) of generalist and specialist small mammal species in secondary forest fragments of the coastal Atlantic Forest, Brazil. Ecological Research, 23(1), 207-215. DOI: 10.1007/s11284007-0366-Z

Reis, F. S., Barros, M. C., Fraga, E. C., Penha, T. A., Teixeira,W. C., Santos, A. C. G., \& Guerra, R. M. S. N. 2008. Ectoparasitos de pequenos mamíferos silvestres em áreas adjacentes ao rio itapecurú e área de preservação ambiental do Inhanum, estado do maranhão, Brasil. Revista Brasileira de Parasitologia Veterinária, 17, 6974.

Ribeiro, V. L. S., Weber, M. A., Fetzer, L. O, \& Vargas, C. R. B. 1997. Espécies e prevalência das infestações por carrapatos em cães de rua da cidade de Porto Alegre, RS, Brasil. Ciência Rural, 27 (2), 285-289. DOI: 10.1590/S0103-8478199700 0200019

Rolstad, J. 1991. Consequences of forest fragmentation for the dynamics of bird populations: conceptual issues and the evidence. Biological Journal of the Linnean Society, 42(1-2), 149-163. DOI: 10.1111/j.1095-8312.1991.tb00557.x

Ruiz, A. 2001. Plague in the Americas. Emerging infectious diseases, 7, 539-540.

Saatchi, S., Agosti, D., Alger, K., Delabie, J., \& Musinsky, J. 2001. Examining fragmentation and loss of primary forest in the southern Bahian Atlantic forest of Brazil with radar imagery. Conservation Biology, 15, 867-875. DOI: 10.1046/j.1523-1739.2001.015004867.x

Sabatini, G. S., Pinter, A., Nieri-Bastos, F. A., Marcili, A., \& Labruna, M. B. 2010. Survey of 
ticks (Acari: Ixodidae) and their Rickettsia in an Atlantic Rain Forest Reserve in the state of São Paulo, Brazil. Journal of Medical Entomology, 47(5), 913-916. DOI: http://dx.doi.org/10.1603/ ME10073

Santos-Filho, M., Silva, D., \& Sanaiotti, T. 2008. Edge effects and landscape matrix use by a small mammal community in fragments of semideciduous submontane forest in Mato Grosso, Brazil. Brazilian. Journal of Biology, 68(4), 703-710. DOI: 10.1590/S1519-698420080 00400004

Saraiva, D. G., Fournier, G. F. S. R., Martins, T. F., Leal, K. P., Vieira, F. N., Câmara, E. M. V. C., Costa, C. G., Onofrio, V. C., Barros-Battesti, D. M., Guglielmone, A. A., \& Labruna, M. B. 2012. Ticks (Acari: Ixodidae) associated with small terrestrial mammals in the state of Minas Gerais, southeastern Brazil. Experimental and Applied Acarology, 58(2), 159-66. DOI: 10.10 07/s10493-012-9570-9

Silva, J. M. C., \& Casteleti, C. 2003. Status of the biodiversity of the Atlantic Forest of Brazil. In: C. Galindo-Leal \& I. G. Câmara (Eds.), The Atlantic Forest of South America: biodiversity status, threats, and outlook. pp. 43-59. Washington: Conservation International.

Small, M. F., \& Hunter, M. L. 1975. Forest fragmentation and avian nest predation in forested landscapes. Oecologia, 76(1), 62-64. DOI: 10.1007/BF00379601
SOS Mata Atlântica \& INPE (Instituto Nacional de Pesquisas Espaciais). 2001. Atlas dos remanescentes florestais da Mata Atlântica e ecossistemas associados no período de 2014- 2016. Retrieved on June 6, 2018, from https://www. sosma.org.br.

Stanko, M., Miklisová, D., Bellocq, J. G., \& Morand, S. 2002. Mammal density and patterns of ectoparasite species richness and abundance. Oecologia, 131, 289-295. DOI: 10.1007/s00442002-0889-5

Szabó, M. P. J., Nieri-Bastos, F. A., Spolidorio, M. G., Martins, T. F., Barbieri, A. M., \& Labruna, M. B. 2013. In vitro isolation from Amblyomma ovale (Acari: Ixodidae) and ecological aspects of the Atlantic rainforest Rickettsia, the causative agent of a novel spotted fever rickettsiosis in Brazil. Parasitology, 140 (6), 719-728. DOI: 10.1 017/S0031182012002065

Yoshizawa, M. A. C., Souza, J. L., Bredt, A., \& Baggio, D. 1996. Ectoparasitos de Rattus norvegicus no Distrito Federal, Brasil. Revista Brasileira de Parasitologia Veterinária, 5, 39-42.

Submitted: 16 September 2014 Accepted: 30 June 2016 Associate Editors: Mariana Ferreira \& Natalie Olifiers 